\title{
VOZES [DIS]SONANTES
}

\section{Andréa Figueiredo Leão Grants ${ }^{*}$ Izabele Cristini da Silva** Jair Zandoná*** Leticia Goellner ${ }^{* * * *}$ Stélio Furlan ${ }^{* * * * *}$ Universidade Federal de Santa Catarina}

Para a revista Anuário de Literatura 2015 está sendo um ano bastante produtivo. Se o primeiro número [Especial] foi dedicado a Italo Calvino, a edição que temos o prazer de apresentar está permeada de múltiplos e significativos olhares. Comecemos pela seção temática Estudos subalternos, organizada pelo Prof. Dr. Cláudio Celso Alano da Cruz, a qual propõe um debate sobre como os subaltern studies (que tem Gayatri Chakravorty Spivak e seu conhecido texto Pode o subalterno falar? referência teórica incontornável) vêm sendo desenvolvidos no país. Nesse sentido, recomendamos especial leitura do texto introdutório elaborada pelo organizador, uma vez que tece algumas reflexões a esse respeito, ao considerar um conceito outro de literatura que seja verdadeiramente democrático e inclusivo.

A necessidade de pensarmos sobre culturas outras, das culturas populares - vistas como sinônimo de subalternas - levou-nos a pensar em como poderíamos representar desde a capa as possibilidades e discussões aqui propostas de modo a envolver os debates sobre arte, política e as questões das subalternidades. Tal anseio levou-nos a navegar às terras moçambicanas de Malangatana Valente Ngwenya. Sua obra é mundialmente reconhecida,

Esta obra está licenciada sob uma Licença Creative Commons.

\footnotetext{
* Doutoranda e Mestre em Literatura pela UFSC. Bibliotecária do Sistema de Bibliotecas da UFSC. Coordenou o Portal de Periódicos UFSC (2009/jun.2014). Integra a Comissão Editorial da Anuário de Literatura.

** Mestranda do Programa de Pós-Graduação em Literatura da UFSC e integra a Comissão Editorial da Anuário de Literatura.

${ }_{* * * * *}^{*}$ Doutor em Literatura pela UFSC, integra a Comissão Editorial da Anuário de Literatura.

**** Doutoranda no Programa de Pós-Graduação em Estudos da Tradução na UFSC. Colabora no periódico Cadernos de Tradução. Integra a Comissão Editorial da Revista Anuário de Literatura.

Doutor pela Universidade Federal de Santa Catarina. Atualmente é Professor Associado junto ao DLLV/UFSC. Atual Editor-Chefe da Revista da ANPOLL e Editor da Revista Anuário de Literatura.
} 
assim como seu envolvimento das lutas de libertação e, após a independência e cessar da guerra civil, seu engajamento na política.

Oportunamente, ao falar sobre sua produção artística, Malangatana afirmou que há "sempre uma manancial de temas a abordar. São os acontecimentos do mundo, às vezes tristes, outras alegres, e eu não fico indiferente. Seja me Moçambique, ou noutra parte do mundo, a dor humana é a mesma" (Cf. a matéria do Jornal Hoje Macau, de 06 de janeiro de 2011, quando noticiou o falecimento de Malangatana). Daí que a tela intitulada Encruzilhada de Culturas torna-se ainda mais significativa para dialogar com os debates propostos neste número. Formas, traços, cores, gestos, expressões. Pessoas, culturas, tempos e espaços que se - e são - atravessados pelo instante-agora.

Mas além da seção temática, temos a satisfação de mencionar os artigos com temática livre que compõem a edição. Em Febo Apolo na trama épica de "Memorial da Infancia de Christo e Triumpho do divino Amor" (1639) de Soror Maria de Mesquita Pimentel Fabio Mario da Silva investiga a representação da figura de Apolo nessa epopeia religiosa. Viajando além-mar, Maurício Silva, em História e identidade na ficção de José Eduardo Agualusa analisa a literatura angolana, em particular a produzida por Agualusa, considerando as (co)relações entre os conceitos de história, identidade e o discurso anticolonialista.

O texto Poética da criação verbal: a crítica polifônica nos estudos da linguagem literária, de Augusto Rodrigues da Silva Junior e Ana Clara Magalhães de Medeiros, articula os estudos sobre a crítica polifônica de e sobre Mikhail Bakhtin para pensar sobre a Teoria da Literatura, suas interpretações e sua práxis na vida humana. Por sua vez, Robson Batista dos Santos Hasmann, com Uma literatura globalizada: o corpo literário de "Favelost", de Fausto Fawcett, dedica sua atenção a essa narrativa contemporânea brasileira através das discussões entre literatura e tecnologia, especialmente sobre a ciberficção. Marlene Rodrigues Brandolt estabelece relações, em $A$ crítica feminista articulada ao literário, os estudos de gênero e a crítica literária feminista pensando os entrecruzamentos possíveis entre ficção e realidade nas obras Navegações (cuja primeira edição foi lançada em 1983), de Sophia de Mello Andresen, e $O$ rio do meio (1996), de Lya Luft. Além desses artigos, a resenha de Monique Bione - Arquivos, imagens e percursos em "Ablativo" - dedicada a essa publicação realizada em 2014 a qual contou com o trabalho de tradução de Patricia Peterle, Silvana de Gaspari e Andrea Saturbano. 
Por fim, queremos agradecer à Fundação Mário Soares/Fundo Malangatana Valente Ngwenya por ter gentilmente autorizado a divulgação da pintura disponível no acervo do Portal Casa Comum. Além disso, reforçamos uma vez mais nossos agradecimentos a Cláudio Cruz por aceitar nosso convite para organizar a seção temática. Acreditamos que o trabalho de editar uma revista acadêmica é, acima de tudo, coletivo e colaborativo. 